\title{
Crustacean microcoprolites from Lower Cretaceous and Oligo-Miocene deposits, Persian Gulf, Iran
}

\author{
MARYAM DALVAND*, ALI REZA ASHRAFZADEH \& ZAHRA AHMADI \\ Mapsa Company, Geological Department, Tehran 1431854864, Iran \\ *Corresponding author (e-mail: Maryam.dalvand@yahoo.co.uk)
}

\begin{abstract}
Biostratigraphical observations in different locations and horizons of carbonate strata from four oil wells drilled in the Persian Gulf Basin document three new ichnospecies of crustacean microcoprolites. Favreina irannensis n. sp. occurs in Valanginian-Hauterivian strata of the Buwaib Formation (Gadvan Formation), Palaxius asmariensis n. sp. in the Lower Miocene strata of the Asmari Formation, and Palaxius minaensis n. sp. in the Aptian strata of the Dariyan Formation.
\end{abstract}

KEYWORDS: microcoprolites; Lower Cretaceous; Persian Gulf; Palaxius; Favreina

\section{INTRODUCTION}

Records of crustacean microcoprolites from Iran, especially in the Persian Gulf are scarce. Brönnimann (1977) described Favreina tabasensis from the Upper Jurassic of the Tabas area of Iran. Around the world generally crustacean microcoprolites have been reported by several authors from the Palaeozoic to Cenozoic. For example, Favreina carpatica was described by Senowbari-Daryan et al. (2013) from the Middle Jurassic of the southern Carpathians. From Neocomian strata, Brönnimann (1976) revised Favreina salevensis Paréjas, 1948. In addition, faecal pellets have been reported from the Oligocene of Turkey by Altinli (1942), from the Jurassic of Switzerland by Joukowsky \& Favre (1913), from the Mesozoic of France by Cuvillier \& Sacal (1956), from the Upper Jurassic and Lower Cretaceous of Cuba by Paréjas (1948) and Brönnimann (1955), and from the Triassic to Miocene of the Middle East by Elliott $(1962,1963)$. A circular cross-section with tiny spherical, hook-shaped and crescentic canals that are regularly arranged are important characteristics of microcoprolites. Variety of arrangement, number and shape of internal longitudinal canals permit separation of forms such as Favreina Brönnimann, 1955, Palaxius Brönnimann \& Norton, 1960 and Parafavreina Brönnimann, 1972. Among Decapoda crustaceans, four families are known that produce microcoprolites: Galatheidae, Thalassinidae, Upogebidae and Callianassidae (Moore, 1932, 1933; Blau et al., 1993). Recently, well-preserved microcoprolites produced by decapod crustaceans were identified (Senowbari-Daryan et al., 2009). The ichnogenus Palaxius embraces 22 ichnospecies, from the Permian to Tertiary, which were listed with their morphological characteristics in Senowbari-Daryan \& Kube (2003). The genus is recognized for the first time from the Carboniferous, Palaxius salataensis (Masse \& Vachard, 1996), and ranges up to the Miocene (Paganelli et al., 1986). This study is focused on the introduction and description of new crustacean microcoprolites that have not been reported previously from the Persian Gulf region.

\section{GEOLOGICAL SETTING AND STUDIES}

The Persian Gulf Basin is situated between the Arabian Shield in the west, Taurus Mountains in the north and the Zagros Orogenic
Belt in the east and NE (Konyuhov \& Maleki, 2006). The samples containing microcoprolite ichnofossils were collected from different stratigraphic locations and horizons of four oil fields from the Persian Gulf (Fahliyan Formation from the SR field, Dariyan Formation in the CR field, Buwaib Formation in the WIW7 Field, and the Asmari Formation from the AB field; Fig. 1). The detailed lithologies of these formations are given below.

In the SR field, the microcoprolites were found only in the Fahliyan Formation, which consists of limestone interbedded with argillaceous limestone, marl, and thin layers of dolomite at approximately $53.20 \mathrm{~m}$ depth. The ichnogenus Favreina is associated with foraminifera: Everticyclammina, Permocalculus, Actionoporella, Pseudolitunella, Charentia, Trocholina, Mayncina, Nautiliculina, Derventina, Glomospirella and miliolids. The abundance of algal fragments in intervals of this limestone indicates the presence of an algal mound formed in the inner ramp region.

The Dariyan Formation in the CR Field consists of $44 \mathrm{~m}$ of shallow-water limestone formed on the inner to mid-ramp, with marl and argillaceous limestone from an open marine environment. The microcoprolites in this interval occur in two distinct types of microfacies: 'bioclastic wackestone-mudstone' which belongs to the outer ramp, and 'boundstone' and 'bioclasticOrbitolina wackestone-mudstone' facies that have been referred to the inner ramp depositional environment. In the first microfacies, foraminifera of Hedbergella species, Globigerinelloides, Neotrocholina, Mesorbitolina, Choffatella and Epistomina are present. Most of the foraminifera present belong to the outer ramp environment. The second microfacies contains benthic foraminifera Archaeoalveolina, Nezzazata, Pseudocrysalidina, Salpingoporella, Voloshinoides, Nezzazata, Nezzazatinella and Praechrysalidina and algae such as Lithocodium and can be assigned to the inner ramp environment. It is noteworthy that according to Feldmann et al. (2007) the microcoprolites present in the Dariyan Formation belong to blind decapods (lack of eyes as in Tricarina sp.), adapted to an aphotic and open-marine deep-water environment that is represented by Barremian-Aptian strata of the Zagros area.

In WI-W7 Field, a $58 \mathrm{~m}$ thick sequence of Buwaib Formation of late Neocomian age is considered to be a shallow-water 

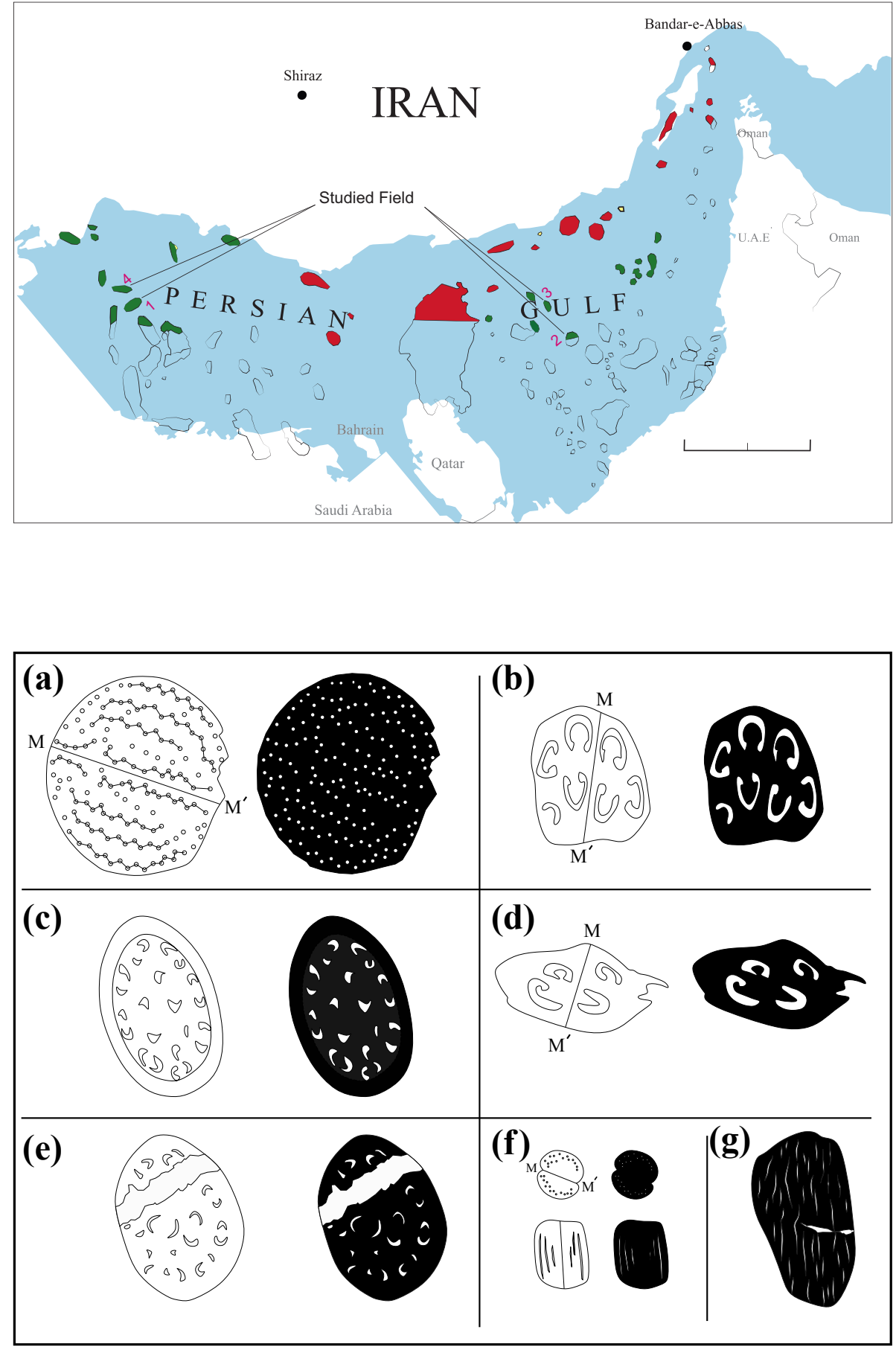

Fig. 1. Location map of the studied fields in the Persian Gulf: (1) SR, (2) CR, (3) WI-W7 and (4) AB.
Fig. 2. Schematic diagrams of microcoprolite and mirror plan of

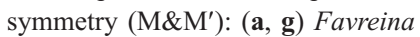
iranensis n. sp.; (b) Palaxius asmariensis n. sp.; (c, e) Palaxius minaensis n. sp.; (d) Palaxius sp.; (f) Favreina sp.

Fig. 3. Photomicrographs of thin sections of studied crustacean microcoprolites. (a, b) Favreina iranensis $\mathrm{n}$. sp.: (a) holotype, longitudinal section and (b) transverse section, WI-W7 field, depth 2475.05 m, Buwaib Formation. (c) Palaxius minaensis n. sp., holotype, CR field, depth $1552.30 \mathrm{~m}$, Dariyan Formation. (d) Favreina iranensis n. sp., paratype, WI-W7 field, depth 2471.21 m, Buwaib Formation. (e) Favreina sp., SR field, depth $2759.77 \mathrm{~m}$, Fahliyan Formation. (f) Palaxius asmariensis n. sp., holotype, AB field, depth $864.05 \mathrm{~m}$, Asmari Formation. (g) Palaxius sp. AB field, depth $858.80 \mathrm{~m}$, Asmari Formation. (h) Palaxius minaensis n. sp., paratype, CR field, depth $1575.90 \mathrm{~m}$, Dariyan Formation. 

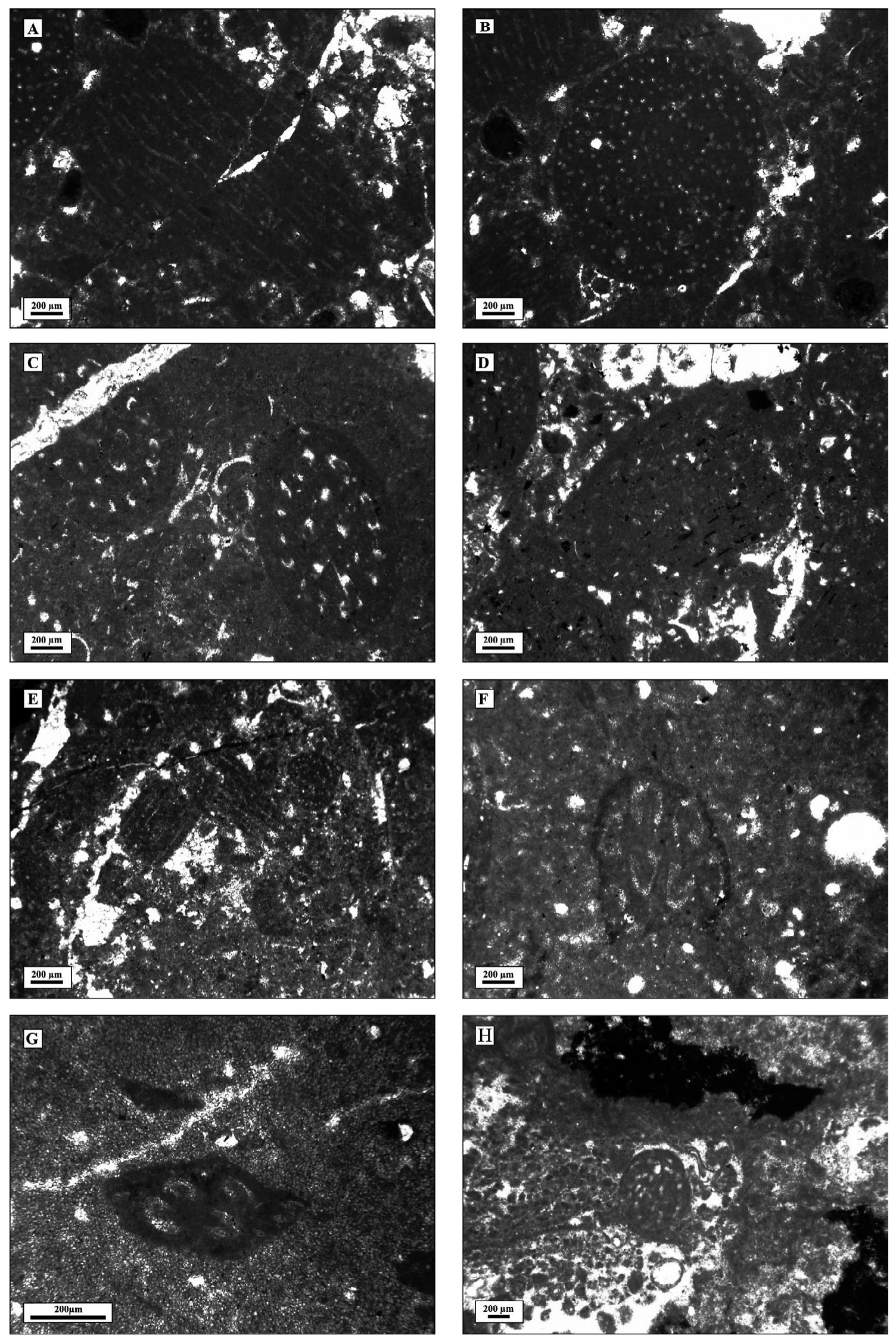
bioclastic limestone and argillaceous limestone. Based on sedimentological and micropaleontological studies of the Buwaib Formation and the presence of foraminifera such as Clypeina, Actinoporella and Trocholina, calcareous sponge spicules, and dasyclad algal fragments, the 'foram algal debris wackestone' and 'peloid bioclastic packstone to grainstone' microfacies can be assigned to lagoonal and back shoal environments (that is the sections containing Favreina).

The Asmari Formation in the AB Field, about $39 \mathrm{~m}$ thick, is highly variable and consists of anhydritic dolomite, anhydrite, argillaceous limestone, dolomitic limestone, dolomite, limestone, limy dolomite, sandy dolomite and shale. The microfacies (of the interval containing Palaxius) includes two types: the 'Microbialite' and 'Coated grain Packstone-Grainstone' facies that can be referred to lagoonal and back shoal depositional settings, respectively. The microbialite facies is dominated by microbial structures that were produced by microbial processes in shallow-water environments. In this microfacies, lagoonal foraminifers such as Dendritina, Elphidium, Rotalia and Archaias are found. The second microfacies is a back shoal setting.

Thus, microcoprolite ichnofossils in these four different locations are generally located in lagoonal and back shoal environments. Only in the Aptian (Dariyan Formation) are microcoprolites observed in both lagoonal and open marine environments.

\section{SYSTEMATIC PALAEONTOLOGY}

Material is deposited in the collections of the National Iranian Oil Company, Tehran.

Class Crustacea Pennant, 1777

Order Decapoda Latreille, 1802 Infraorder Thalassinidea Latreille, 1831

Superfamily Thalassinoidea Latreille, 1831

Ichnofamily Favreinidae Vialov, 1978

Ichnogenus Favreina Brönnimann, 1955

Favreina iranensis n. sp.

(Figs 2a, g and $3 \mathrm{a}-\mathrm{b}$, d)

Origin of the name. From the occurrence of the coprolite in Iran.

Holotype. Thin section WI-W7/B 2475.05 (Fig. 3a-b).

Paratypes: Thin sections WI-W7/B 2475.05, WI/B 2471.21 (Fig. 3d).

Type locality. WI-W7 Oil Field, Persian Gulf, Iran (Fig. 1, location 3).

Type stratum: Upper Neocomian (Valanginian-Hauterivian) limestone of Buwaib Formation.

Description and dimensions. Favreina Brönnimann, 1955 is characterized by the numerous longitudinal canals arranged bilaterally in a symmetrical plane.

Favreina iranensis n. sp is represented by transverse and longitudinal sections (Figs 2a, g and $3 \mathrm{a}, \mathrm{b}$ ). The diameter of the transverse section is $600 \mu \mathrm{m}$ and the length of the longitudinal section is about $900 \mu \mathrm{m}$. The ichnospecies is penetrated by 165 longitudinal canals with an average diameter of about $15 \mu \mathrm{m}$. Internally it has canals arranged in bilaterally symmetrical zigzag microstructures.
Generally, four curved rows are visible in lateral cuts and some erratic pores are located among them. The length of the curved series increased from the centre of the microcoprolite towards the periphery. These zigzag lines are converted to straight lines towards the axis of symmetry $\left(\mathrm{M}, \mathrm{M}^{\prime}\right)$. Also, a pair of hookshaped curved canal sets is seen (on the $\mathrm{M}$ axis). Each row consists of approximately 15-19 channels (Fig. 2a, g).

Comparisons. Favreina tabasensis Brönnimann, 1977 was described from the Upper Jurassic of the Tabas area, eastern Iran. There are some similarities and differences between this species and $F$. iranensis n. sp.: the number of curves and canals (4 curves and 113 canals in $F$. tabasensis and 5 curves and 165 canals in F. iranensis n. sp.), the diameter of the canals $(25 \mu \mathrm{m}$ in F. tabasensis and nearly $15 \mu \mathrm{m}$ in our new species), the form of the curves (curves in F. tabasensis are completely zigzag form but in $F$. iranensis n. sp. the sides are smooth) are some of these differences. Also, Favreina salevensis Paréjas, 1948 differs with regard to the shape of the curves and diameters of the canals in crosssection (range from about 23 to $39 \mu \mathrm{m}$ ), that is larger than in the new species. Based upon the above-mentioned features and special characteristics we introduce Favreina iranensis n. sp.. In the Buwaib Formation the new ichnospecies is associated with foraminifers Pseudocyclammina, Pseudochrysalidina species, Praechrysalidina, Trocholina species and Neocomian index algae like Salpingoporella species and Actinoporella. A ValanginianHauterivian age is assigned to this assemblage.

\section{Favreina sp.}

(Figs 2f, 3e)

Remarks. The size of this species is smaller than in Favreina iranensis n. sp.. It is impossible to determine the original shape and number of canals of this form properly due to the poor preservation. It has a spherical shape with two depressions at the poles (Fig. 2f). The transverse section is about $200 \mu \mathrm{m}$ in diameter and the length of the longitudinal section is nearly $400 \mu \mathrm{m}$. The general arrangement of the longitudinal canals as seen in the transverse section (Fig. 2f) is nearly zigzag, but the central part of the coprolite is not clear.

$$
\begin{aligned}
& \text { Ichnogenus Palaxius Brönnimann \& Norton, } 1960 \\
& \text { Palaxius minaensis n. sp. } \\
& \text { (Figs 2c, d and 3c, h) }
\end{aligned}
$$

Origin of the name. Fom the Iranian name of a black bird (Mina), after the occurrence of the coprolite.

Holotype. Thin section Cr/D 1552.30 (Fig. 3c).

Paratype. Thin section Cr/D 1575.90 (Fig. 3h).

Type locality. CR Oil Field. Persian Gulf, Iran (Fig. 1, location 2).

Type stratum. Aptian age medium- to thick-bedded limestone and argillaceous limestone of the Dariyan Formation.

Description and dimensions. This microcoprolite has an oval outline and a cross-section of 500 to $800 \mu \mathrm{m}$ in diameter. Canals in this species are crescent-shaped and consist of 22 in number (e.g. eleven binary groups) (Fig. 2c, e). The lengths of the longitudinal 
canals are from 50 to $90 \mu \mathrm{m}$ and widths approximately $25 \mu \mathrm{m}$. An axial imaginary plane divides these canal sets into two asymmetrical parts that may be due to depositional pressure. These longitudinal canals are arranged in 11 bilaterally symmetrical groups of 22 canals. The eight groups located at the periphery of the specimen and the rest are scattered in the centre. A characteristic feature of this species is a dark margin around canals in transverse section.

Comparisons. It is noteworthy that Palaxius asmariensis n. sp. is different from Palaxius minaensis n. sp. in the hook-shape of the longitudinal canals in transverse section and in their number. $P$. minaensis $\mathrm{n}$. sp. is also different from $P$. mendozaensis Kietzmann, 2009 with 12 longitudinal hook-shaped canals. The new ichnospecies is associated with foraminifera Hedbergella, Choffatella, Epistomina and Globigerinelloides sp. of Aptian age.

Palaxius asmariensis n. sp.

(Figs 2b and 3f)

Origin of the name. After the occurrence of the new coprolite ichnospecies in the Asmari Formation.

Holotype. Thin section Ab/A 864.05 (Fig. 3f).

Paratype. Thin section Ab/A 864.05 (Fig. 2b).

Type locality. AB Field, Persian Gulf, Iran (Fig. 1, location 4).

Type stratum. Limestone and sandy limestone of the Asmari Formation, Lower Miocene.

Description and dimensions. The ichnospecies Palaxius asmariensis n. sp. is characterized by the presence of longitudinal canals with hook-shaped outline, arranged bilaterally to a symmetrical plane (Brönnimann, 1972). This species has a diameter of about 600 to $700 \mu \mathrm{m}$ in transverse section.

P. asmariensis n. sp. has seven internal canals, six of them are symmetrical around the plane M, M' (Fig. 2b). Probably half of these additional canals were lost due to pressure and depositional deformation. Thus, there is strong likelihood that this species had 8 canals. The length and width of the canals are $300 \mu \mathrm{m}$ and $30-50 \mu \mathrm{m}$. They are orientated at $30^{\circ}\left(\mathrm{a}, \mathrm{a}^{\prime}\right)$ and $90^{\circ}\left(\mathrm{b}, \mathrm{b}^{\prime}\right)$ from the bilaterally symmetrical plane.

Comparisons. P. asmariensis n. sp. is differentiated from all other Palaxius (e.g. P. caracuraensis Kietzmann, 2009, P. azulensis Kietzmann, 2009, P. decaochetarius Palik, 1965) by the orientation and number of canals. Although the position of the canals in this species is approximately similar to $P$. decemporatus Senowbari-Daryan, 1979, their number and shape are different. Also, $P$. hydranensis, described by Senowbari-Daryan \& Kube (2003) from the Triassic of Greece, is distinct in the number and shape of canals.

\section{Palaxius sp. \\ (Figs 2e and 3g)}

Remarks. The diameter of this species is about 250 to $350 \mu \mathrm{m}$. Although it is possible to observe four canals in the symmetrical plane, it seems that this species is similar to Palaxius asmarensis described above. Canals are $100 \mu \mathrm{m}$ in length and $25-30 \mu \mathrm{m}$ in width. Senowbari-Daryan et al. (2009) recognized P. caucaensis Blau et al., 1995 in the Upper Cretaceous of Egypt, which is similar to this species in the number and orientation of the canals (Fig. 2e). Due to poor preservation this species could not be referred to a specific form.

\section{SUMMARY AND CONCLUSIONS}

Records of crustacean fossils from Iran are extremely scarce, thus, assigning the ichnospecies introduced above to a genus of crustaceans is difficult. Portunus withersi (Glaessner, 1933) and Cancer craniolaris (Linnaeus, 1758) are two of the reported decapod crustacean species occurring only in the Middle Miocene of southern Iran (cited in Heidari et al., 2012 and Yazdi et al., 2013) so the ichnogenus Palaxius material described here from the Lower Miocene could not be referred to these decapods. At the present time, the ichnogenus Palaxius is thought to have been produced by Callianassa and Protocallianassa (Moore, 1939; Blau \& Grün, 2000), while the ichnogenus Favreina belongs to the Thalassinidae family. Three ichnospecies that were described in this article, Palaxius asmariensis $\mathrm{n}$. sp., Palaxius minaensis n. sp. and Favreina iranensis n. sp., are recorded for the first time from the Persian Gulf.

Using microcoprolites to determine the age and correlation of host sediments is doubtful and they cannot be considered good indices. However, Kietzmann et al. (2009) differentiated two microcoprolite assemblages in time, one from the Tithonian to early Valanginian and another from the early to late Valanginian. In this study, from detailed benthic foraminifera and other micropalaeontological analyses, the Early Miocene age for the Asmari Formation microcoprolites was determined. Also based upon foraminifera and algae a Neocomian (Berriasian-Valanginian age) for the Fahliyan Formation, a Valanginian-Hauterivian age for the Buwaib Formation, and an Aptian age for the Dariyan Formation were confirmed.

\section{ACKNOWLEDGEMENTS}

We sincerely thank R. Feldmann for kindly annotating a draft manuscript and for help with language, and special thanks go to R. Feldmann and C. Schweitzer for their reviews and technical assistance. The authors are grateful to the Mapsa (Abdal Industrial Projects Management Co.) for their institutional support for the research. We also extend our thanks to the Editor-in-Chief, Alan Lord, and Production Editor, Sarah Gibbs, for their help and guidance.

\section{Manuscript received 17 November 2014 \\ Manuscript accepted 2 February 2015}

Scientific editing by Alan Lord.

\section{REFERENCES}

Altinli, E. 1942. Étude géologique de la chaîne côtière entre BandirmaGemlik. Revue de la Faculté des Sciences de l'Université d'Istanbul. Série B, Tome VIII, 8: 76-137.

Blau, J. \& Grün, B. 2000. Liste der bekannten Gattungen und Arten. FAVRIS - interactive database on structured crustacean coprolites, https:// www.staff.uni-giessen.de/ gg13/FAVRIS/DECAPODA/ARTN_IDX.HTM

Blau, J., Grün, B. \& Gießen, M.S. 1993. Crustaceen-Koprolithen aus der Trias der westlichen Tethys (Lienzer Dolomiten, Österreich; Pragser Dolomiten, Italien) und vom Gondwana-Westrand (oberes Magdalenatal, Kolumbien, Südamerika). Paläontologische Zeitschrift, 67: 193-214.

Blau, J., Moreno, M. \& Senff, M. 1995. Palaxius caucaensis n. sp., a crustacean microcoprolite from the basal Nogales Formation (Campanian to Maastrichtian) of Colombia. Micropaleontology, 41: 85-88.

Brönnimann, P. 1955. Microfossils incertae sedis from the Upper Jurassic and Lower Cretaceous of Cuba. Micropaleontology, 1: 28-51. 
Brönnimann, P. 1972. Remarks on the classification of fossil anomuran coprolites. Paläontologische Zeitschrift, 46: 99-103.

Brönnimann, P. 1976. Revision of the lectotype of Favreina salevensis (Paréjas) (Crustacea, Decapoda) and description of favreine form-species from the Jurassic and Cretaceous of Scotland, Portugal, Yugoslavia and Pakistan. Paläontologische Zeitschrift, 50: 40-56.

Brönnimann, P. 1977. A new farina coprolite (Crustacea, Decapoda) from the Jurassic of Iran and the Cretaceous of the Dinarids, Jugoslavia. Paläontologische Zeitschrift, 51: 94-101.

Brönnimann, P. \& Norton, P. 1960. On the classification of fossil fecal pellets and description of new forms from Cuba, Guatemala and Libya. Eclogae Geologiae Helvetiae, 53: 832-842.

Cuvillier, J. \& Sacal, V. 1956. Stratigraphic Correlations by Microfacies in Western Aquitaine. 2nd edn. E.J. Brill, Leiden, 33pp.

Elliott, G.F. 1962. More microproblematica from the Middle East. Micropaleontology, 8: 29-44.

Elliott, G. 1963. Problematical microfossils from the Cretaceous and Paleocene of the Middle East. Palaeontology, 6: 293-300.

Feldmann, R.M., Kolahdouz, A., Biranvand, B. \& Schweigert, G. 2007. A new family, genus, and species of lobster (Decapoda: achelata) from the Gadvan Formation (Early Cretaceous) of Iran. Journal of Paleontology, 81: 405-407.

Heidari, A., Feldmann, R.M. \& Moussavi-Harami, R. 2012. Miocene decapod crustacean from the Guri Member of the Mishan Formation, Bandar-Abbas, Southern Iran. Bulletin of Mizunami Fossil Museum, 38: $1-7$.

Joukowsky, E. \& Favre, J. 1913. Monographie géologique et paléontologique du Salève (Haute Savoie). Mémoires de la Société de Physique et d'Histoire Naturelle de Genève, 37: 295-519.

Kietzmann, D.A., Blau, J., Fernandez, D.E. \& Palma, R.M. 2009. Crustacean microcoprolites from the Upper Jurassic-Lower Cretaceous of the Neuquén Basin, Argentina: Systematics and biostratigraphic implications. Acta Palaeontologica Polonica, 55: 277-284.

Konyuhov, A. \& Maleki, B. 2006. The Persian Gulf Basin: Geological history, sedimentary formations, and petroleum potential. Lithology and Mineral Resources, 41: 344-361.
Masse, P. \& Vachard, D. 1996. A crustacean coprolite, Palaxius salataensis, in the Upper Carboniferous of the southern Urals. Neues Jahrbuch für Geologie und Paläontologie-Monatshefte, 8: 490-494.

Moore, H.B. 1932. The faecal pellets of the Anomura. Proceedings of the Royal Society of Edinburgh, 52, 296-308.

Moore, H.B. 1933. The faecal pellets of Hippa asiatica. Proceedings of the Royal Society of Edinburgh, 56: 252-254.

Moore, H.B. 1939. Faecal pellets in relation to marine deposits. In Trask, P. (Ed.), Organic Content of Recent Marine Sediments: Part 6. Special Features of Sediments. American Association of Petroleum Geologists, Special Volume, 4: 516-524.

Paganelli, V.M., Pichezzi, R. \& Zuccari, A.T. 1986. I coproliti di crostacei-rassegna bibliografica e annotazioni tassonomiche. Parte II: Generi Helicerina, Palaxius, Parafavreina et Thoronetia. Bolletino del Servizio Geologico d'Italia, 104: 309-344.

Palik, P. 1965. Remains of crustacean excrement from the Lower Cretaceous of Hungary. Micropaleontology, 11: 98-104.

Paréjas, E. 1948. Sur quelques coprolithes de Crustacés. Archives des Sciences, 1: 512-520.

Senowbari-Daryan, B. 1979. Anomuren-Koprolithen aus der Obertrias der Osterhorngruppe (Hintersee/Salzburg, Österreich). Annalen des Naturhistorischen Museums Wein, 82: 99-107.

Senowbari-Daryan, B. \& Kube, B. 2003. The ichnogenous Palaxius (crustacean coprolite) and description of $P$. hydranensis $\mathrm{n}$. sp. from the Upper Triassic (Norian part of 'Pantokrator' limestone) of Hydra (Greece). Paläontologische Zeitschrift, 77: 115-122.

Senowbari-Daryan, B., Nagm, E., Blau, J. \& Wilmsen, M. 2009. Crustacean microcoprolites from the Upper Cretaceous of Egypt. Revue de Paléobiologie, 28: 511-518.

Senowbari-Daryan, B., Lazar, I. \& Bucur, I.I. 2013. Favreina carpatica n. ichnosp. (Crustacea, Microcoprolite) from the Middle Jurassic of Rucar-Bran Zone (Southern Carpathians, Romania). Rivista Italiana di Paleontologia e Stratigrafia, 119: 175-182.

Yazdi, M., Bahrami, A., Abbasi, P., Sadeghi, R. \& Vega, F.J. 2013. Miocene brachyuran Crustacea from Konar-Takhteh and Ahram sections, southwestern Iran. Boletín de la Sociedad Geológica Mexicana, 65: 225-233. 